\title{
Un estudi sobre la sexualitat a Espanya
}

\author{
Teresa Abelló \\ Universitat de Barcelona \\ Facultat d'Història \\ Departament d'Història i Arqueologia \\ Montalegre, 6 \\ 08001 Barcelona
}

Jean-Louis Guereña, Detrás de la cortina. El sexo en España (I8701950), Madrid, Cátedra, 2018

Els hàbits i comportaments sexuals dels ciutadans han estat un tema tradicionalment poc tractat per la historiografia, particularment l'espanyola, que sí que ha estudiat amb més rigor altres comportaments socials en el marc de la història sociocultural. En general, el pudor que impregna el tema, o el respecte a la intimitat de l'individu, ha fet que fos un tema tabú, i oblidat pels estudiosos al moment d'analitzar comportaments socials. Aquesta dinàmica s'ha trencat a partir dels nombrosos treballs sorgits en el marc de la historiografia nord-americana i anglosaxona. També en la historiografia espanyola han aparegut en les darreres dècades treballs interessants sobre sexologia, estimulats en part per l'interès creixent pels estudis de gènere. El llibre de Jean-Louis Guereña Detrás de la cortina. El sexo en España (I870-1950) constitueix, en aquest sentit, una aportació fonamental.

Guereña, catedràtic emèrit de la Universitat François-Rabelais Tours, prestigiós hispanista i estudiós de la història social i cultural d'Espanya dels segles XIX i XX, amb reconeguts treballs sobre diversos aspectes de l'obrerisme a Espanya, s'ha endinsat des de fa anys en els estudis sobre la sexualitat des de perspectives diverses. Aquest llibre, editat originàriament en francès l'any 2013 i degudament revisat, ha

AbelLó, Teresa (2020), «Un estudi sobre la sexualitat a Espanya». Cercles. Revista d'Història Cultural, 23, 239-243. ISSN: 1139-0158. ISSN-e: 1699-7468. DOI: 10.1344/cercles2020.23.1015. Data de recepció: 22/4/2020. Data d'acceptació: 4/6/2020. 
estat recentment traduït i publicat en castellà per l'editorial Cátedra, cosa que constitueix un encert perquè posa a l'abast no només dels estudiosos, ja versats en els escrits de Guereña, sinó del públic hispà en general, un treball que s'inscriu de ple en la recerca de la història social espanyola. El llibre, amb un amplíssim suport bibliogràfic en tots els capítols, és resultat de la compilació de diversos treballs sobre el tema, alguns ja publicats anteriorment per l'autor en diferents formats i altres d'inèdits, que són un clar reflex de l'àrdua tasca de documentació portada a terme per l'autor.

El llibre, ortodoxament acadèmic, té una introducció àmplia on Guereña s'esplaia analitzant la manera com la historiografia contemporània ha abordat els estudis sobre la sexualitat amb matisos particulars: l'anglosaxona —extensa i metodològicament innovadora, i, tanmateix, sempre amb una mirada condescendent respecte al sud d'Europa-, la francesa —més historicista, utilitzada per l'autor com a patró d'anàlisi- o l'espanyola — més escassa i que majoritàriament arrenca en l'àmbit de la història de la medicina i/o en els espais més feministes.

L'autor dona al treball un enfocament sociocultural, ja que analitza la història de la sexualitat a Espanya des de diferents punts de vista al llarg d'un segle i mig, si bé se centra — malgrat el que s'especifica en el títol — en l'espai cronològic comprès entre el darrer quart del segle xix i fins a l'època de la Segona República. El llibre, molt extens, amb més de sis-centes pàgines, està organitzat en deu capítols que estan agrupats en tres parts: «El descubrimiento del sexo», "La prostitución ¿un mal necesario?» i «Erotismo y pornografía: un “infierno" español». En la primera, "El descubrimiento del sexo», dividida en dos capítols, l'autor repassa les col-leccions populars de llibres i fullets d'educació i divulgació sexual que es van publicar a Espanya al llarg dels segles XIX i xx, i analitza les característiques i particularitats de cada una. Els arquetips eren diversos: algunes es presentaven com a publicacions amb voluntat informativa, però, pel seu contingut, la frontera entre la medicina sexual i l'erotisme sovint

Cercles. Revista d'Història Cultural, 23 (2020), 239-243.

ISSN: 1139-0158. e-ISSN: 1699-7468. DOI: 10.1344/cercles2020.23.1015. 
és confusa, alhora que s'hi evidencia una complaença a explicitar els vicis $\mathrm{i}$ les perversions sexuals que alimentaven l'imaginari sexual masculí; altres, més populars, amb una difusió més àmplia, presentaven un contingut més en consonància amb el que s'esperava de les relacions matrimonials més tradicionals. En aquest apartat també es dedica una atenció especial a l'aparició, l'etimologia, la història i la difusió del preservatiu masculí, entès tant com un element orientat a la contracepció com un per a la higiene sexual.

La segona part, «La prostitución ¿̇un mal necesario?», està dedicada a estudiar el paper i el pes de la prostitució i els prostíbuls en una societat de forta tradició catòlica com l'espanyola. En el text es visualitzen les diferents posicions morals i ideològiques des de les quals s'ha tractat la prostitució, s'analitzen les regulacions policials, els tractats higienistes, el posicionament de corrents ideològics més alternatius i testimonis històrics de caire divers. L'apartat està organitzat a partir de tres eixos: l'estudi de les diverses reglamentacions que van afectar la prostitució, el bordell com a espai de sociabilitat i la recepció a Espanya de les campanyes abolicionistes promogudes a la Gran Bretanya a finals del segle xIx. La prostitució era acceptada en la catòlica Espanya com un mal social inevitable, i com a tal s'havia de reglamentar i contenir en espais controlats per no interferir en l'ordre moral establert. En aquest apartat adquireix rellevància l'estudi del bordell com a espai de sociabilitat. La reglamentació era, a la fi, fruit d'un acord implícit entre metges i autoritats policials i religioses, i podia servir de profilaxi social. Hi havia una tolerància social de la prostitució i en el llibre s'estudia el sistema sanitari aplicat en aquest camp i el funcionament dels sistema policial establert per regular/controlar l'activitat.

Un punt destacat és l'atenció que es dedica a les repercussions que van tenir a Espanya les campanyes abolicionistes llançades per corrents feministes britànics — la més destacada, la de Joséphine E. Butler, que va fundar la Federació Continental i General Britànica el 
I875- que s'oposaven a qualsevol tipus de reglamentació de la prostitució, en nom del benestar de les prostitutes. Malgrat l'atenció que se li dedica, a Espanya aquests corrents van tenir pocs seguidors en el moment en què van aparèixer, i el moviment abolicionista no es va consolidar fins a la època de la Segona República.

La tercera part, "Erotismo y pornografía: un “infierno” español», és de bon tros la més extensa. Està dedicada a fer memòria de com la literatura ha tractat l'erotisme i la pornografia, des dels textos literaris més refinats fins als clarament pornogràfics. Es fa incidència en els llibres prohibits per les autoritats, la Inquisició, per tal de vetllar per la moral de la societat. S'analitzen les diferents teories mèdiques, en especial les de Gregorio Marañón. Es repassen les produccions eròtiques clandestines, literàries o gràfiques, de les diverses èpoques, sobretot dels més liberals anys vint i trenta del segle Xx. Es recull i es fa memòria de la literatura eròtica que es llegia a Espanya, majoritàriament procedent de França i recollida sistemàticament pels censors en els Índices de llibres prohibits. També recull la producció eròtica pròpia, tant la que es difonia de manera clandestina com la que tenia un lloc en els quioscs i espais de venda pública, en definitiva, colleccions populars més o menys picants a l'abast del públic general.

Jean-Louis Guereña constata l'existència d'almenys tres-centes cinquanta colleccions eròtiques que representen uns sis mil títols. Ens relata les estratègies emprades pels autors per amagar els noms reals i pels editors per desviar l'atenció dels censors. Els pseudònims es mostren clarament com a tals, i editorials i llocs d'edició són volgudament fantasiosos i clarament improbables. També s'utilitza la paròdia religiosa, en consonància amb l'anticlericalisme de les darreres dècades del segle XIx i les primeres del xx, per donar noms a autors i editors. Guereña fa un plantejament temàtic de les diferents colleccions eròtiques populars i dedica un punt a analitzar — sense incloure illustracions, per restriccions editorials — la producció erò- 
tica del popular dibuixant barceloní de finals del segle xix Eusebi Planas. L'èxit d'aquesta literatura eroticopornogràfica va provocar la reacció de sectors catòlics, que van impulsar la mobilització de diverses lligues de virtut, tal com va passar en altres països.

El llibre es tanca amb un interessant treball presentat en forma d'epíleg en el qual s'analitza la polèmica sobre la sexualitat que va entretenir l'Espanya dels anys trenta del segle Xx. Aquesta polèmica versava sobre les teories sexuals sostingudes pel prestigiós metge Gregorio Marañón i la confrontació que va mantenir amb Oliver Brachfeld, un humanista hongarès - $\mathrm{i}$, tanmateix, literat, psicòleg i editorinstal.lat aquells anys a Barcelona a causa del seu interès per la psicologia, la història i la literatura catalana, que s'oposava als conceptes humanistes de Marañón, tal com va exposar en la publicació Polémica contra Marañón (1933).

En definitiva, estem davant d'un llibre fonamental que ens aporta una quantitat important d'informació sobre com es vivia la sexualitat a Espanya en el període tractat; això sí, la sexualitat masculina. El llibre és resultat d'una llarga investigació i d'un profund coneixement de les publicacions que s'han fet sobre sexologia i de les fonts hemerogràfiques i d'arxiu. Recull tot tipus d'elements escrits i gràfics referents a la sexualitat: illustracions eròtiques, pornografia, novelles, tractats de diversos tipus (mèdics, religiosos, jurídics, polítics, ideològics, etc.). Ens presenta els diferents autors i analitza les seves argumentacions, tot aportant elements que permeten intuir quin era l'espai social de difusió de cada un. Analitza de manera minuciosa les reglamentacions sobre la prostitució, però és més pobre l'estudi dels diferents espais socials en què aquesta es donava.

El llibre és un acostament intellectual, i tanmateix social i cultural, a com s'ha tractat el tema de la sexualitat a Espanya des de finals del segle XIX fins a mitjan segle Xx, en ple franquisme, amb pinzellades a altres èpoques. La visió dominant, condicionada per les fonts, és eminentment masculina, reflex del model de societat de l'època. 